dollars to the Museums Association for a programme of museum development in Newfoundland, Southern Rhodesia and the Colonies.

\section{A Direct Reading Universal Drawing Compass}

Mr. Thorold, 20, Rathbone Place, W.1, sends us particulars of a new instrument which is a combination of scale and compass. The compass points travel on a beam carrying interchangeable scales. The two points terminate in movable heads on the beam which are adjustable, one possessing a micrometer. The instrument is also supplied with calliper points for external and internal measurements. The maker claims that great accuracy is obtainable, and for fine drawing in the field of physical science and engineering the invention seems likely to be valuable. The cost of the instrument is $\mathfrak{f} 7 \mathrm{~s}$.

\section{Austrian Ethnographical Expedition to West Africa}

AN expedition, of which Dr. Ralph Elber, of the Institute of Egyptology and African Studies, is the leader, left Vienna, according to a communication issued by the Reichszentrale für Wissenschaftliche Berichterstattung, Berlin, early in January for Sierra Leone, whence it will proceed to Liberia for the purpose of exploring the interior of the country and observing the little-known tribes of that region. Special attention will be given to the study of the religious and magical beliefs of the tribes and their languages, which are virtually unknown. The results of this expedition should be of special interest in view of present lack of knowledge of the area, its inhabitants and natural history. It is also hoped to add to the map particulars of one of the last uncharted areas of Africa.

\section{Pittsburgh Award of the American Chemical Society}

THE Pittsburgh Section of the American Chemical Society has selected Dr. Ralph E. Hall, director of the Hall Laboratories, Inc., Pittsburgh, Pa., as the recipient of the 1933 (the first) Pittsburgh Award. This honour, which will be conferred on Dr. Hall at the sectional meeting on February 15, is in recognition of his distinguished service to chemistry and humanity, particularly his contributions to the fundamental knowledge of boiler-water reactions and their applications to the practical solution of boilerwater problems, his discoveries and technical accomplishments in the beneficiation and conditioning of water for industrial and domestic use, and his developments in the production of chemicals for these purposes. The Pittsburgh Award is represented by a plaque of gold, on which the relation of chemistry to industry is symbolised.

\section{Announcements}

Sir Wirltam Larke, K.B.E., Director of the National Federation of Iron and Steel Manufacturers ; Prof. Edward Mellanby, F.R.S., Secretary of the Medical Research Council ; and Mr. Leonard Woolley, Director of the Joint Expedition of the British Museum and of the Museum of the University of Pennsylvania to Mesopotamia, have been elected members of the Athenæum under the provisions of Rule II of the club, which empowers the annual election by the committee of a certain number of persons of distinguished eminence in science, literature, the arts or for public service.

Sir Arthur Eddington will deliver the Rickman Godlee lecture at University College, Gower Street, London, W.C.1, on Friday, February 16, at 5.30 p.m. The subject of Sir Arthur's lecture will be: "The Constitution of the Stars". The lecture will be open to the public.

Prof. A. Zrmmern, Montague Burton Professor of International Relations in the University of Oxford, is giving a course of six lectures (Muirhead Lectures in Social Philosophy) at the University of Birmingham on Thursdays, beginning on February 1, on "Britain and the World Crisis".

Mrss Nina Symingron, daughter of the late Prof. Symington of Belfast, has bequeathed the residue of her estate, amounting to some $£ 9,000$, to be known as the Johnson Symington Memorial bequest, to the Anatomical Society of Great Britain and Ireland for anatomical research.

THE Council of the Institution of Naval Architects has awarded the Gold Medal for the year 1933 to Eng.-Capt. S. R. Dight, for his paper on "Naval Water-Tube Boilers. Experiments and Shop Trials"; and the premium to Dr. George Hughes, of the William Froude Laboratory, for his paper on "The Effect of Wind on Ship Performance".

Aprutcations are invited for the following appointments, on or before the dates mentioned:-A chemical assistant to the advisory chemist in the Department of Agriculture, University of Cambridge - The Secretary, School of Agriculture, Cambridge (Feb. 10). A junior assistant (chemist) in the Royal Gunpowder Factory, Waltham Abbey-The Principal Clerk, Central Office, Royal Gunpowder and Small Arms Factories, Enfield Lock, Middlesex (Feb. 10). A head of the Department of Civil Engineering and Building, and a head of the Science Department in the Lester School and Institute, Shanghai-Messrs. Viney, Price and Goodyear, Empire House, St. Martin's-le-Grand, London, E.C.1 (Feb. 20). A director of the University School of Librarianship at University College, London-The Academic Registrar, University of London, S.W.7 (March 1). A University lecturer in moral science in the University of Cambridge-The Secretary of the Faculty Board of Moral Science, King's College, Cambridge (March 1). A University lecturer in forestry in the Department of Agriculture of the University of Cambridge-The Secretary, School of Agriculture, Cambridge (April 14). A keeper of the Museum at the Victoria University of Manchester-The Registrar (April 30). A research assistant (male) in the Cancer Research Department of the Westminster Hospital, Broad Sanctuary, London, S.W.1-The Secretary. A registration officer and statistician, and a finance officer and accountant for the Potato Marketing Board-The Secretary, Potato Marketing Board, 45 Bedford Square, London, W.C.1. 